УДК 332.122

Павліха Наталія,

доктор економічних наук, професор, Східносвропейський національний університет імені Лесі Українки, кафедра міжнародних економічних відносин і управління проектами, м. Луцьк; ORCID: 0000-0001-5191-242X e-mail: natalia.pavlixa@ eenu.edu.ua

Цимбалюк Ірина, кандидат економічних наук, доцент, Східноєвропейський національний університет імені Лесі Українки, кафедра фінансів, банківської справи та страхування; м. Луцьк; ORCID ID 0000-0003-0506-2262 e-mail: Tsymbaliuk.Iren@eenu.edu.ua

https://doi.org/10.29038/2411-4014-2020-03-136-142

\title{
НАУКОВИЙ БАЗИС ФОРМУВАННЯ ТЕОРІЇ ІНКЛЮЗИВНОГО РОЗВИТКУ РЕГІОНУ
}

У статті дістали подальшого розвитку систематизація та компаративний аналіз теорій регіонального розвитку. Визначено внесок класичних та сучасних теорій регіонального розвитку у формування інклюзивного підходу. Обгрунтовано авторський підхід до визначення поняття «інклюзивний розвиток регіону» як процесу досягнення комплексних якісних і кількісних змін просторової системи, на основі розвитку економічної сфери шляхом збільшення ступеня залучення населення до продуктивної діяльності, формування доступної інфраструктури регіону задля створення рівних можливостей особистого розвитку та забезпечення справедливого розподілу отриманих результатів, що виступає передумовою соціального піднесення, зниження рівня диференціації населення й підвищення рівня його добробуту. Доведена необхідність подальшого дослідження теоретичних та інституційних засад інклюзивного розвитку регіону з огляду на реалізацію політики децентралізації влади та необхідності відповідного фінансового забезпечення цих процесів.

Ключові слова: теорія розвитку регіону, класичні теорії регіонального розвитку, теорія сталого розвитку, теорія інклюзивного зростання, інклюзивний розвиток, децентралізація.

Павлиха Наталья, доктор экономических наук, профессор, Восточноевропейский национальный университет имени Леси Украинки, кафедра международных финансовых отношений и управления проектами; г Луцк

Цимбалюк Ирина, кандидат экономических наук, доцент, Восточноевропейский национальный университет имени Леси Украинки, кафедра финансов, банковского дела и страхования, г. Луцк;

\section{НАУЧНЫЙ БАЗИС ФОРМИРОВАНИЯ ТЕОРИИ ИНКЛЮЗИВНОГО РАЗВИТИЯ РЕГИОНА}

В статье произведено систематизацию и компаративный анализ теорий регионального развития. Определен вклад классических и современных теорий регионального развития в формирование инклюзивного подхода. Обоснованно авторский подход к определению понятия «инклюзивное развитие региона» как процесса достижения комплексных качественных и количественных изменений пространственной системы, на основе развития экономической сферы путем увеличения степени привлечения населения к продуктивной деятельности, формирование доступной инфраструктуры региона для создания равных возможностей личного развития и обеспечения справедливого распределения полученных результатов, что выступает предпосылкой социального подъема, снижение уровня дифференциации населения и повышение уровня его благосостояния. Доказана необходимость дальнейшего исследования теоретических и институциональных основ инклюзивного 
развития региона с точки зрения реализации политики децентрализации власти и необходимости соответствующего финансового обеспечения этих процессов.

Ключевые слова: теория развития региона, классические теории регионального развития, теория устойчивого развития, теория инклюзивного роста, инклюзивное развитие, децентрализация.

\title{
Pavlikha Natalia, \\ Dr. E., Professor, Lesya Ukrainka Eastern European National University, Department of International Economic Relations and Project Management;
}

Lutsk

\author{
Tsymbaliuk Iryna, \\ PhD in Economics, Associate Professor, \\ Lesya Ukrainka Eastern European National University, \\ Department of finance, banking and insurance;
}

Lutsk

\section{SCIENTIFIC BASIS FOR THE FORMATION OF THE INCLUSIVE DEVELOPMENT THEORY OF REGION}

Introduction. The systematization and comparative analysis of regional development theories were further developed in the article. A study of the evolution of regional development theories and highlighted the provisions, principles, and approaches reflected in the concept of inclusive growth, which is based on achieving such a type of socio-economic growth that allows each member of society to feel its results, covering all spheres of life.

The purpose of the article is to conduct a comparative analysis of classical and modern theories of regional development in the context of determining their contribution to the development of inclusive concept and the formation of the author's vision of the concept of "inclusive regional development".

Results. The author's approach to the definition of "inclusive development of the region" as a process of achieving comprehensive qualitative and quantitative changes in the spatial system, based on the development of the economic sphere by increasing the involvement of the population in productive activities, forming an accessible infrastructure of the region to create equal opportunities for personal development the results obtained, which is a prerequisite for social uplift, reducing the level of differentiation of the population and increasing its welfare. The necessity of further research of theoretical and institutional bases of inclusive development of the region in view of realization of policy of decentralization of the power and necessity of the corresponding financial maintenance of these processes is proved.

Conclusions. The contribution of classical and modern regional development theories in the formation of an inclusive approach is determined. It is proved that the rethinking of the essence of development and the acquisition of human-cantered orientation in the current environmental problems has led to the formation of new theoretical foundations, effective concepts, and models of regional growth. Given current trends and targets of the socio-economic growth of the world community, it is argued that the theory of inclusive development of the region is the most promising way to solve the problem of improving the welfare and quality of life.

Keywords: regional development theory, classical theories of regional development, sustainable development theory, inclusive growth theory, inclusive development, decentralization.

Постановка проблеми. В умовах кризових явищ в економіці держави необхідним і нагальним постає здійснення заходів, спрямованих на відновлення та подальшу інтенсифікацію регіонального розвитку. Як свідчить практика, зростаючі економіки низки країн усе частіше стикаються із поглибленням соціально-економічної нерівності та проблемою соціальної ізоляції в процесі розвитку. Це зумовило необхідність змін концептуального підходу щодо реалізації політики регіонального розвитку в умовах сповільнення темпів приросту населення, зміни демографічної структури, що стало однією з вагомих причин для переходу до стратегії розумного, сталого i всеосяжного зростання. Такі тенденції призвели до поширення в економічній літературі досліджень інклюзивного зростання й зосередження уваги на рівності доступу до послуг здоров’я, розвитку людського капіталу, дотримання задовільного екологічного стану довкілля, підвищення соціального захисту та продовольчої безпеки як чинників світової безпеки в широкому розумінні.

Аналіз останніх досліджень і публікацій. Теорія інклюзивного зростання пройшла короткий, 
однак стрімкий шлях еволюції, формуючись під впливом загальних тенденцій розвитку суспільства, а також проблем, що набували більшої ваги в той чи інший період. Ця теорія була досить активно сприйнята широким колом фахівців, а значимість інклюзивного зростання економіки визнана провідними міжнародними організаціями. Проблематиці інклюзивного зростання, його принципів, закономірностей та орієнтирів присвячені роботи як українських [1-4], так і зарубіжних учених [5; 6].

Водночас відмінні підходидо розуміння інклюзивного розвитку свідчать про те, що сьогодні не існує загальноприйнятого визначення і єдиного уявлення про цей процес.

Постановка завдання. Метою статті $є$ проведення компаративного аналізу класичних та сучасних теорій регіонального розвитку в контексті визначення їх внеску у розвиток інклюзивної концепції та формування авторського бачення поняття «інклюзивний розвиток регіону».

Виклад основного матеріалу. Виникнення перших концепцій просторового розвитку припадає на початок XIX ст., на період створення класичних теорій розміщення: концентричних кілець сільськогосподарського зростання (Й. Тюнен, 1830-ті pp.), локаційний трикутник раціонального місця розташування промислового закладу (В. Лаунгардт 1882 р.), індустріальних районів (А. Маршалл, 1890-ті рр.), розміщення промисловості (А. Вебер, 1910-ті рр.), центральних місць (В. Кристаллер, 1930-ті рр.), просторової економічної рівноваги (А. Льош, 1940-ві рр.), розміщення продуктивних сил (У. Айзард, 1960-ті рр.). Ключовою концепцією теорії розміщення стало уявлення про те, що формування оптимальних агломерацій уможливлює економію ресурсів і $є$ основою локального розвитку територій.

Класичні теорії розміщення спрямовувались в першу чергу на досягнення економічного розвитку шляхом економії ресурсів та оптимального розміщення виробництва, що давало можливість швидшого доступу до ресурсів та їх економії, збільшувало продуктивність виробництва. Концентрація виробництва та локальне розміщення сприяло вільному доступу до ресурсів та забезпечувало зростання зайнятості на окремих територіях, ці класичні принципи знайшли своє відображення і у сучасній концепції інклюзивного розвитку. Водночас, таке бачення розвитку регіону ототожнювало його з економічним зростанням. Освоєння нових територій призводило до ускладнення економічних відносин і зростання вартості продукції через віддаленість об'єктів виробництва від сировини та споживачів, тому потреба в раціоналізації їх розміщення стала об’єктивною передумовою подальшого розвитку теорій.

У 50-х рр. ХХ ст. спад промислового виробництва, що розпочався в багатьох країнах, засвідчив неефективність наявних на той період механізмів державної підтримки, що дало поштовх до формування нових теорій і переходу від галузевого до регіонального бачення розвитку. Важливе значення на цьому етапі відіграли праці У. Айзарда, який у своїх дослідженнях відстоював інтегровану модель регіонального розвитку, наводив модель просторової рівноваги та розглядав суперечності в регіональних системах. Відтоді регіон сприймається науковцями як окрема соціально-економічна система. Проблема його розвитку набуває міждисциплінарного характеру, іiі розв'язання більше не обмежується економічною сферою, а визнається ії̈ залежність від соціальних, політичних й інших чинників і їх взаємодії. Розуміння комплексності та взаємозалежності розвитку регіону від збалансованого функціонування усіх сфер життєдіяльності людини, що є характерною рисою інклюзивного зростання, набуває особливого наукового інтересу та змінює вектор досліджень.

У цей період набуває актуальності наукове осмислення проблеми міжрегіональної нерівності та нерівномірності процесів розвитку, що відображається у теорії кумулятивного зростання (полюсів зростання (Ф. Перру, 1950-ті рр.), дифузії інновацій (Т. Хагерстранд, 1950-ті рр.), кумулятивного зростання (Г. Мюрдаль, 1960-ті рр.) й ін.). Привабливість регіону для розміщення нових підприємств та ефекти від концентрації в економічно розвинутих регіонах розглядаються розробниками нової концепції як основні чинники випереджального розвитку, що поглиблюють його нерівномірність та потребують активного втручання держав у регіональний розвиток. На сьогодні територіальна рівномірність економічного розвитку та якості життя, вирівнювання та усунення регіональних диспропорцій узгоджуються із цілями інклюзивного розвитку й набувають особливої актуальності за умов децентралізаційних змін, які посилюють роль територій у вирішенні проблем економічного зростання.

Нерівномірність розвитку територій, обгрунтована в межах теорії кумулятивного зростання, 
обумовила необхідність подальшого розвитку концепцій, спрямованих на зниження міжрегіональних диспропорцій та поширення переваг економічного піднесення на всі регіони країни, що відповідає принципам інклюзивного зростання та закладено в основу інклюзивної концепції.

Внесок неокласичних теорій економічного зростання, які виникли у 60-х рр. ХХ ст., у розвиток концепції інклюзивного розвитку регіону полягає в зменшенні міжрегіональних асиметрій шляхом застосування механізму «стихійного ринку», згідно з яким фактори виробництва перетікають у ті регіони, де за них платять більшу ціну (Дж. Бортс і Дж. Стейн (1960-ті рр); Г. Зіберт 1990-ті; Р. Барро 1990-ті; Р. Солоу (2000-ні); Р. Холл, Ч. Джонс (1990-ті) та ін.). До ключових факторів регіонального зростання неокласики відносили транспортні витрати, соціальні, політичні, географічні чинники. Вирівнювання розвитку регіонів пояснювали наростаючою мобільністю факторів виробництва (теорія регіонального зростання Дж. Бортса й Дж. Стейна). Тобто доступ до ресурсів визначався одним із основних чинників розвитку регіону та зниження диференціації між ними, що підтримує концепцію інклюзивного зростання.

У подальшому представниками неокласичної теорії із традиційними факторами були враховані й інші детермінанти економічного зростання, що враховуються у концепції інклюзивного розвитку регіону - соціальні, інституціональні, політичні, географічні. Зокрема, Р. Холл і Ч. Джонс [7, с. 83116] у своїй моделі регіонального зростання розглядають вплив інституціональної політики на формування економічного середовища, стимулювання виробничої активності, упровадження нових технологій, що дозволяе збільшити зайнятість населення, підвищити його продуктивність. Такий підхід є близьким за змістом до концепції інклюзивного розвитку регіону, адже досягнення соціально-економічного зростання регіонів є неможливим без ефективних інститутів та створення системи їх активної взаємодії.

У контексті дослідження генезису теорії інклюзивного розвитку регіону вартими уваги є теорії, що виникли наприкінці XX ст., які сформовані під впливом інформаційного й технологічного суспільного розвитку. Вони висвітлювали концепцію нового економічного зростання: нового інформаційного суспільства (Дж. Нейсбіт, 1980-ті рр.), «нового регіоналізму» (М. Кітінг), інституціональної адаптації до змін (Д. Норт), міжнародної торгівлі, агломерацій (П. Кругман), регіональних інноваційних систем (Б. Асхайм та А. Ізаксен).

Починаючи з 80-х рр. ХХ ст., характер, якість і стійкість регіонального розвитку в соціальному, екологічному, політичному та культурному вимірах поступово стають у центрі економічних досліджень. Міжрегіональні нерівності в стандартах життя й добробуті ставлять під сумнів спроможність традиційних економічних індикаторів адекватно відображати суть $\mathrm{i}$ зміст регіонального розвитку. Згідно альтернативних підходів до аналізу визначення регіонального розвитку починає асоціюватися із зниженням соціальної нерівності, рівними можливостями для усіх верств населення, підвищенням екологічної стійкості та посиленням безпеки.

Наприкінці XX ст. особливої ваги набуває концептуальний підхід, який грунтується на зростанні регіональної конкурентоспроможності, що є продовженням кумулятивної теорії, теорії полюсів зростання та дифузії. Теорії зростання за рахунок конкурентних переваг регіону аналізують причини й чинники формування конкурентних переваг регіону, що зумовлюють підвищення рівня продуктивності праці та, як наслідок, - зростання валового регіонального продукту. Близькість концептуальної ідеї теорії конкурентоспроможності регіону до концепції інклюзивного розвитку полягала у налагодженні таких відносин між усіма регіональними суб'єктами, які приводять до новацій, інтеграції на основі спільних інтересів та спільних узгоджених дій для забезпечення територіального розвитку й створення якісного життєвого середовища.

Новітній етап розвитку регіональної науки був окреслений зміною орієнтації на внутрішній потенціал і пошук власних можливостей території до самодостатнього зростання. Ключовим фактором ендогенного зростання постає змінна, яка називається «знання», або «інформація». Потрібно зазначити, що фактор соціального капіталу, який є одним із ключових у концепції інклюзивного зростання, набув важливості у формуванні теорій регіонального розвитку лише на початку XXI ст.

У світі дедалі більше загострювались екологічні проблеми, що стали наслідками економічного зростання. Регіональні стратегії повинні були забезпечувати те, щоб розвиток виробництва й збільшення кількості робочих місць не суперечили інтересам охорони довкілля, а економічні 
суб'єкти мали відповідати за завдані ними збитки.

Близькою до концепції інклюзивного зростання $\epsilon$ теорія сталого розвитку, що сформувалася внаслідок поступового усвідомлення суспільством необхідності враховувати «співвідношення поточних та перспективних життєвих потреб як країни у цілому, так і кожного іії регіону зокрема» $[8$, c. 11]. Теорія передбачає «процес виживання та відтворення генофонду нації, активізацію ролі окремо взятої людини в суспільстві, забезпечення ii прав та свободи, збереження довкілля, формування умов для відновлення біосфери та іiі локальних екологічних систем» [9].

Одним із шляхів розв'язання проблем сталого розвитку визнано запровадження альтернативної стратегії, що грунтується на підвищенні інтенсивності праці, тобто збільшенні відношення праці до капіталу та зменшенні кількості енергії та природних ресурсів. Ці ідеї в подальшому покладено в основу розробки теорії інклюзивного розвитку регіону, що досягається шляхом максимального залучення усіх верств суспільства до продуктивної праці, зниження диференціації в рівнях доходів і підвищення добробуту населення.

Уперше термін інклюзії застосовано в 1970-х роках у США, але тоді виділяли лише соціальну інклюзію, під якою розуміли збільшення ступеня участі всіх громадян у соціумі, коли кожна людина як індивідуальність сприймається суспільством і має можливість повноцінно брати участь у соціумі [3].

В основі інклюзивного розвитку лежить необхідність забезпечення участі населення країни у процесі зростання як з точки зору прийняття рішень, так і у формуванні факторів зростання. Цей тип соціально-економічного зростання спрямований на розвиток людини, підвищення ії добробуту та зниження рівня бідності та нерівності, вимагає активної участі в економіці людського ресурсу. Інклюзивний підхід забезпечує справедливі можливості й рівноправ'я для економічних учасників, дає змогу залучити більшу частину трудових ресурсів до ефективної діяльності, що супроводжується вигодами, принесеними кожному сектору економіки та різним верствам суспільства [10, с. 235-240].

Отже, систематизація та компаративний аналіз теорій регіонального розвитку та зародження інклюзивної концепції зростання, аналізу теоретичних підходів до визначення сутності інклюзії дає можливість наукової ідентифікації поняття «інклюзивний розвиток регіону» як процесу досягнення комплексних якісних і кількісних змін просторової системи, на основі розвитку економічної сфери шляхом збільшення ступеня залучення населення до продуктивної діяльності, формування доступної інфраструктури регіону задля створення рівних можливостей особистого розвитку та забезпечення справедливого розподілу отриманих результатів, що виступає передумовою соціального піднесення, зниження рівня диференціації населення й підвищення рівня його добробуту.

Останніми роками в наукових працях з регіональної економіки акценти щодо підвищення ефективності соціально-економічного зростання переносяться саме на місцевий рівень, що обумовлено поширенням децентралізаційної теорії управління в країнах світу [11]. Тому дослідження генезису теорій регіонального розвитку та зародження інклюзивної концепції набувають особливої ваги в контексті визначення перспектив їх адаптації до потреб розвитку регіону в умовах децентралізаційних змін.

Конкретизуючи проблему інклюзивного розвитку регіонів за умов українських реалій, необхідним $є$ врахування децентралізаційних процесів та набуття органами місцевої влади значних повноважень у прийнятті рішень щодо забезпечення соціально-економічного зростання відповідної території й забезпечення комфортного середовища життєдіяльності населення громади. Звертаючись до досліджень К. Боса і Дж. Гупти складовими частинами інклюзивного напряму розвитку регіону можемо визначити [5, с. 484]: а) справедливий розподіл благ і рівних можливостей для всього населення; б) економічні можливості для підвищення рівня зайнятості населення громад; в) громадська участь та інклюзивні інститути; г) екологізація розвитку; г) згладжування потрясінь й адаптивна спроможність до змін.

У проекті Стратегії сталого розвитку України до 2030 р. [12] серед визначених завдань поряд із децентралізацією та впровадженням регіональної політики, яка передбачає гармонійне поєднання загальнонаціональних і регіональних інтересів; передбачено побудову мирного та безпечного, соціально згуртованого суспільства з належним врядуванням й інклюзивними інституціями.

Розробка та реалізація заходів у межах інклюзивного розвитку повинна сприяти скороченню міжрегіональної диференціації, досягнути чого можна, стимулюючи зацікавленість місцевого 
самоврядування й жителів громад у зростанні продуктивності праці, зниженні витрат, шляхом дотримання принципів зеленої економіки, запровадження інновацій тощо. 3 іншого боку, відмінність у наявному природо-ресурсному, трудовому потенціалі, стані та структурі господарства різних територій зумовлюють нерівні можливості їх потенційного зростання й доводять необхідність створення системи взаємодопомоги між регіонами задля згладжування початкових відмінностей у рівнях економічного та соціального розвитку.

Висновки. Отже, пошук ефективної моделі регіонального розвитку призвів до виникнення широкої низки теорій, які своїми завданнями ставлять забезпечення соціально-економічного зростання й добробуту населення. Однак кожна з них по-своєму інтерпретує цільові пріоритети та шляхи виконання цих завдань, обгрунтовує відмінний набір інструментів і засобів досягнення цілі.

Переосмислення сутності розвитку та набуття ним людиноцентристського спрямування на фоні критичного стану наявних екологічних проблем зумовило формування нових теоретичних засад, ефективних концепцій і моделей регіонального зростання. Ураховуючи сучасні тенденції та цільові орієнтири соціально-економічного піднесення світової спільноти, вважаємо теорію інклюзивного розвитку регіону, що є квінтесенцією еволюції теоретичних моделей регіонального зростання, найбільш перспективним шляхом розв'язання проблеми підвищення рівня добробуту та якості життя населення.

\section{Джерела та література}

1. Возняк Г. В. Регіональний розвиток: сутність і методологічна основа. Регіональна економіка. 2015. № 3. С. 34-43.

2. Кожина А. В. Теорія інклюзивного місцевого розвитку та ії взаємозв'язок з теоріями територіального розвитку. Інвестииії: практика та досвід. 2018. № 22, С. 102-109.

3. Сапун В. К., Селезньова В. Р. Концепція інклюзивного зростання в економіці. Вісник студентського наукового товариства ДонНУ імені Василя Стуса. 2018. № 10. С. 177-181.

4. Федулова Л. І. Інклюзивні інновації в системі соціально-економічного розвитку. Економіка: реалії часу. 2016. № 3 (25). C. 56-65.

5. Bos K., Gupta J. Inclusive development, oil extraction and climat echange: a multilevel analysis of Kenya. International Journal of Sustainable Development \& World Ecology. № 23:6. 2016. P. 482-492.

6. Ianchovichina E. and Lundstrom Gable S. "WhatisInclusiveGrowth?" in Commodity Pricesand Inclusive Growthin Low-Income Countries, ed. by R. Arezki, C. Pattillo, M. Quintyn, and M. Zhu, International Monetary Fund, 2012 .

http://siteresources.worldbank.org/EXTPREMNET/Resources/WhatIsIG.pdf?resourceurlname=WhatIsIG.pdf （дата звернення: 18.07.2020).

7. Robert E. Hall and Charles I. Jones. Why Do Some Countries Produce So Much More Output Per Worker Than Others? The Quarterly Journal of Economics, Oxford University Press. Vol. 114, №. 1 (Feb., 1999), pp. 83-116. URL: http://www.jstor.org/stable/2586948 (дата звернення: 20.06.2020).

8. Павліха Н. В. Управління сталим розвитком просторових систем: теорія, методологія, досвід: монографія. Луцьк: Волин. обл. друк., 2006. 380 с.

9. Павліха Н. В. Концептуальні засади управління сталим розвитком просторових систем. Луцьк: Надстир'я, 2005. 60 с.

10. Цимбалюк І. О. Генезис теорії інклюзивного розвитку регіону. Причорноморські економічні студіï. Одеса, 2019. Вип. 47. С. 235-240.

11. Цимбалюк I. О. Інклюзивний розвиток регіону в умовах фінансової децентралізаиії: теорія, методологія, практика. Луцьк: Вежа-Друк, 2019. 340 с.

\section{References}

1. Vozniak H. V. (2015). Rehionalnyi rozvytok: sutnist i metodolohichna osnova [Regional development: essence and methodological basis]. Regional economy. № 3, 34-43. [in Ukrainian].

2. Kozhyna A. V. (2018). Teoriia inkliuzyvnoho mistsevoho rozvytku ta yii vzaiemozv'iazok z teoriiamy terytorialnoho rozvytku [The theory of inclusive local development and its relationship with theories of territorial development]. Investytsii: praktyka ta dosvid, 22, 102-109 [in Ukrainian]. 
3. Sapun V. K., Seleznova V. R. (2018). Kontseptsiia inkliuzyvnoho zrostannia v ekonomitsi [The concept of inclusive growth in the economy]. Visnyk studentskoho naukovoho tovarystva DonNU imeni Vasylia Stusa. 10, 177181 [in Ukrainian].

4. Fedulova L. I. (2016). Inkliuzyvni innovatsii v systemi sotsialno-ekonomichnoho rozvytku [Inclusive innovations in the system of socio-economic development]. Ekonomika: realii chasu, 3 (25), 56-65 [in Ukrainian].

5. Bos K., Gupta J. (2016). Inclusive development, oil extraction and climat echange: a multilevel analysis of Kenya. International Journal of Sustainable Development \& World Ecology. № 23: 6. P. 482-492. [in English].

6. Ianchovichina E. and Lundstrom Gable S. "WhatisInclusiveGrowth?" in Commodity Pricesand Inclusive Growthin Low-Income Countries, ed. by R. Arezki, C. Pattillo, M. Quintyn, and M. Zhu, International Monetary Fund, 2012. Available http://siteresources.worldbank.org/EXTPREMNET/Resources/WhatIsIG.pdf?resourceurlname=WhatIsIG.pdf 18.07.2020) [in English].

7. Robert E. Hall and Charles I. Jones (1999). Why Do Some Countries Produce So Much More Output Per Worker Than Others? The Quarterly Journal of Economics, Oxford University Press. Vol. 114, №. 1 (Feb., 1999), pp. 83-116. Available at: http://www.jstor.org/stable/2586948 (дата звернення: 20.06.2020) [in English].

8. Pavlikha N. V. (2006). Upravlinnia stalym rozvytkom prostorovykh system: teoriia, metodolohiia, dosvid [Management of sustainable development of spatial systems: theory, methodology, experience]. Lutsk: Volyn. obl. druk., 380 [in Ukrainian].

9. Pavlikha N. V. (2005). Kontseptualni zasady upravlinnia stalym rozvytkom prostorovykh system [Conceptual principles of management of sustainable development of spatial systems]. Lutsk: Nadstyr'ia, 60 [in Ukrainian].

10. Tsymbaliuk I. O. (2019). Genesis of the regional inclusive development theory. Prychornomorski ekonomichni studii. Odesa, 47, 235-240 [in Ukrainian].

11. Tsymbaliuk I. O. (2019). Inkliuzyvnyi rozvytok rehionu $v$ umovakh finansovoi detsentralizatsii: teoriia, metodolohiia, praktyka [Inclusive development of the region in terms of financial decentralization: theory, methodology, practice]. Lutsk: Vezha-Druk, 340 [in Ukrainian].

Стаття надійшла до редакції 12.08.2020 р. 